\title{
Innovations Around Mobile Applications: Scope for Indian Developers
}

\author{
Meghna Rishi \\ Lal Bahadur Shastri Institute of Management, New Delhi
}

\begin{abstract}
This paper explores innovations around mobile applications, globally, and brings out the scope for monetization of these trends, by Indian Application Developers.

The paper is based on qualitative research and utilizes Content Analysis Technique for tabulating and reporting the data. A thorough literature review has been conducted to understand the innovations around mobile applications globally and to identify the top 5 categories of mobile applications. These categories serve as variables for understanding the scope for Indian mobile application developers. Data on Indian Mobile application market has been sourced from mass media: Top 3 English newspapers (Indian) and 6 online sources. Recommendations for Indian developers have been generated on the basis on data which was reported under 5 identified categories of mobile applications.

Scope for Indian Mobile application developers is in (but not limited to) the following areas; Developing cloud enabled applications, developing customised Indian applications, working on innovations based on global acceptability through multi-language apps., synchronising data with backend systems and addressing security threats, reducing costs through prudent locations and newer API's (Application Programming Interface), beta testing applications and appropriate keyword tagging for marketing and making applications oriented towards customer delight so that in the process of diffusion of the innovation, the application becomes an integral part of the customer's life.

Methodical content analysis brings out the scope for Indian application developers and offers them valuable insights on monetization tactics. Since the findings are based on published data from Indian Mass Media, it makes the paper very contemporary and the recommendations very implementable for the industry. Academicians working in this area too, will also find an avenue for further exploration.

This research work is distinctive because of the lack of scholarly studies in this area, especially in the Indian context. Data from mass media and use of content analysis - a widely used qualitative analytic method for a scholarly study, increases its value by making the work recent, contemporary and worthy of further scholarly explorations.
\end{abstract}

Keywords: Technology Management, Mobile Application, Content Analysis, Smartphone, India, Software Development, Marketing.

\section{INTRODUCTION}

$\mathbf{M}$

obile applications (apps.) are meant for mobile devices, tablet PC and other portable media players and are a "lighter version of computer applications"(Research on India, 2012). The market for Mobile applications has been accelerating towards growth and is expected to achieve a growth rate of $807 \%$, to reach a user base of 1 billion by 2013 , from 100 million, recorded in 2009 (Rasheed, 2012). This is supported by the fact that

Journal of Technology

Management for Growing Economies Vol. 3 No. 2 October 2012 pp. $119-136$

\section{ChITKARA 司 UNIVERSITY}

CC2012 by Chitkara University. All Rights Reserved. 

International Telecommunications Union projected the worldwide count of mobile users as, more than 6 billion, in 2011 and further suggested that each of them typically has mobile devices that are "smart enough". Especially in markets like Japan, China, France, Malaysia, Singapore, US and India the demand of smart phones, multi functional mobile phones, iPhones, Blackberry phones and Android enabled phones is rapidly rising (Poitou, 2010). The Android Market which is also popularly called 'Google Play', has its reach in 190 countries and $67 \%$ of its revenues, generate outside USA( Google Developers, 2012). Hence the market for mobile application development offers an extremely lucrative ground for novice as well as seasoned developers (Daily Nation, 2012) in developed economies as well as in India.

Since mobile phones today are used as a computer, music player, a navigation unit, a notepad, a search device and lot more, various consumer based, as well as business based mobile applications are being developed in the industry. Technology giants of the world including Google and Yahoo have been quick in responding to this environment and have introduced various mobile applications that let the users search for relevant information through newer modalities (The Official Google Blog, 2008). Such applications are supported by various algorithms that the company (offering the mobile application) creates so that ambient systems or pervasive computing can facilitate the weaving together of computing with communication (Scmitt et. al, 2008; Euzenat et. al, 2008). However, success of these mobile applications is based on the relevance of the information that they offer to the users or in other words, the ability of the application to decipher the context of users and offer results, information or solutions in tandem with the user's situation, so that the end result is more personalised, relevant and user friendly (Schmitt et. al, 2008; The Google Official Blog, 2009). Hence, the simple concept of an algorithm, being a sequence of activities aimed at achieving a computing task, seems to be getting altered to, an algorithm being a series of steps, directed by a computing task, leading towards a specific output, which fits in a finite range of output specifications. In other words, it aims at getting the best results using limited resources (Satyanarayanan and Narayanan, 2001).

The Indian Mobile Industry, which has a great role in offering considerable economic gains to the economy, generates a substantial 
revenue through various Value Added Services and mobile application (Gupta et.al, 2005). Consumers who visited app stores in India, till October 2010, grew by $108 \%$ since 2009 and the sales for smartphones witnessed an year on year growth of $294.9 \%$ (Lobo, 2011). The Indian Application Development market alone, is expected to grow by $22.6 \%$ (from 2011 to FY 2012) to reach \$ 227 million (Biztech2, 2012). To multiply this growth trend, Indian developers would have to valueadd by identifying cash cow opportunities like, the development of customer- engaging mobile applications for businesses, since $90 \%$ of Fortune 2000 companies do not offer any mobile applications to their customers( Rasheed, 2012).

In this backdrop, the present research paper sheds light on global innovations around mobile applications and highlights the scope for monetization of these trends, by the Indian Application Developers. This paper examines the popular categories of mobile applications, along with technological advancements in application development and offers insights to Indian developers, thereby facilitating their ride, on this growth wave.

\section{METHODOLOGY}

This empirical study is qualitative in nature. The research method utilised is content analysis since this technique allows the measurement of variables as they occur naturally (Neuendorf, 2002). First a thorough literature review was conducted to identify the emerging innovations in mobile and Smartphone applications. Data, pertaining to the development of mobile applications in India, was sourced from mass media because content analysis, allows a researcher to describe published content (during a given time frame) with an aim of identifying what exists in reality (Wimmer and Dominick, 2011). Berger ( 2012) describes Content Analysis as a technique that helps in the measurement of a specified variable, through various forms of communication. Similar methodology had been adopted by Sapolsky et. al. (2003), when they studied "slasher" movies to establish an understanding on the depiction of sex and violence, and their consequent impact on the society.

\section{ANALYTIC PROCEDURE}

The study was carried out in the following stages, as elaborated in Figure 1. These stages have been suggested by Neuendorf, 2002,
Innovations Around Mobile Applications 
Rishi, M.

while discussing the process which must be followed for Content Analysis Research.

Published newspaper articles ( in the time period: January 2012- August 2012), from the top three English dailies of India (Indian Readership Survey Q4, 2011) , have been content analysed to offer insights for Indian Application developers. These newspapers include:

- The Times of India

- Hindustan Times

- Hindu

Published Online articles ( in the time period: January 2012- August 2012), were also studies for the purpose of collecting exhaustive data. These have been sourced from the following websites (based on their established credibility and the frequency with which this content gets published in the mentioned media.):

- Rediff.com

- Economictimes.com

- Hindu Business Line

- Biztech2.com( website from Network 18)

- Exchange4media.com

- NDTV Online

Based on thorough literature review , 5 categories were identified for analysing the scope for Indian mobile application developers. These categories were analysed based on the time spent per active user, on them worldwide ( Flurry Analytics, 2011). These are: Photo \& Video; Music; Productivity; Social Networking; Entertainment . The growth rates of each of these categories, for a period ranging from October 2011 to March 2012, are mentioned below in parenthesis:

- Photo and Video (89\%)

- Music (72\%)

- Productivity (66\%)

- Social Networking (54\%)

- Entertainment (40\%)

The same have been cross validated by the report on 101 top mobile applications ( PC World, 2012) . 
1. Theory and Rationale: Published newspaper articles from 3 leading Indian dailies and 6 online sources, were used to gather data, around the scope for Indian Application developers

2. Conceptualisation : Based on thorough literature review, the scope for Indian mobile application developers, was analy sed under 5 Categories of Applications.
Innovations

Around Mobile

Applications

3. Measures : To establish data validity, only that news/ information was considered, which had appeared in more than one publication

4. Coding Schemes: Broad variables that emerged from literature review, was broken in to codes and coding scheme was developed ( to record data which emerged from sources mentioned in stage 2)
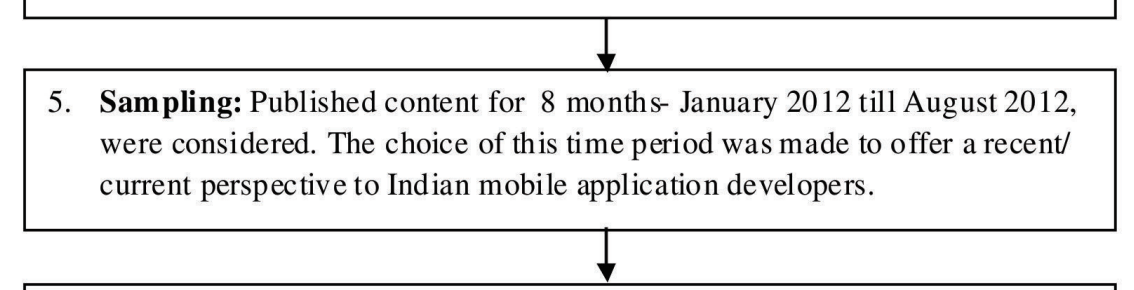

6. Coding: Content from the sample was analysed and coded in the developed coding scheme

7. Tabulation and Reporting: The results were reported under identified variables, in the form of descriptive narrative. This was followed by thorough analyses and recommendations

Figure 1: Stages of Content Analysis for this Research

\section{MOBILE APPLICATIONS AND TECHNOLOGY}

Mobile applications and emerging trends in pervasive computing operate through varied and multiple components, spread across a wide geographical area, like the "context aware intelligent transportation systems" (Meier, 2010), GPS and Satellite Imagery on hand held devices like the Cell phones (Johnson, 2008) or the ability of connecting the camera of a mobile phone to the computing 
Rishi, M.

cloud, in order to search for unidentified stimulants (Krazit and Shankland, 2009). Today, every device can be connected to every other device and connectivity has swept the world to an extent that individuals can control their televisions, which are at their homes, from their mobile phones. Such ease of connection and control comes from the emergence of powerful clouds. Clouds have been credited with the onus of changing the way mobile applications get developed and practised. Even "traditional application developers" are now forced to "cloud- enable" their offering (Tejaswni, 2012) Clouds offer a huge amount of compute resources that programmers have to their disposal. In other words, clouds relate to data centres which are hosts to massive amount of computational power, with the ability to manipulate huge data models. Cloud Computing presents endless resources virtually that are accessible on demand and charged according to usage (Miettinen \& Nurminen, 2010). Hence, the combination of three C's-Computing, Connectivity and Cloud has led to a technological outburst where mobile phones have become powerful devices having the capability to do innovative functions like retrieving memory and acting like a personal memory archive for the user or even have the capability of "realtime motion recognition" through the use of accelerometers, which could help users, for instance, to identify that a session of exercise made them loose how many calories and they would benefit from how much more physical activity (Gyorbiro et. al, 2008). Technology of in build sensors in Smart Phones has made these devices capable of performing extraordinary activities and when these sensors get connected to the clouds, their power magnifies and the Smart Phones then become capable of performing complex function like inputting user query by voice and providing the exact results on the phone, in a fraction of seconds. Mobile devices can also offer the customers Internet access, which is supported by Wireless Application Protocol. This is extremely relevant in the light of the fact that access to Internet, in the $21^{\text {st }}$ century, is demanded by consumers irrespective of the location, time or the device with which they are connected (Maamar, 2006).

Applications for mobile devices interact with varied technological elements including the network infrastructure, the hardware of the mobile phone and the operating system of the mobile (Karvonen and Warsta, 2004 as cited in Tarnacha and Maitland, 2008) and hence offer the results of their functionality. This interaction of the mobile application with the mentioned technological elements is possible because of Application Programming Interface( API's), which are like interaction points for varied softwares (Tarnacha and Maitland, 2008; Bloch, 2006). Local API's offer ease in access to "cameras, microphones, storage, accelerometers and a growing collection of 
information sources on handsets" (Berg, 2011). Mobile operating systems like Symbian, RIM(Research In Motion) Blackberry, Linux and Palm (McLean, 2009) and middlewares like Sun's Java ME eases the functioning of mobile applications further (Tarnacha and Maitland, 2008).

While developing applications, developers need to identify the platforms on which, the applications will run. These can be native development tools/ platforms like Apple iOS, Android, RIM Blackberry, Symbian, Microsoft Phone 7 or cross platform environments like "including mobile enterprise application platforms such as SAP AG's Sybase Unwired

Platform, Kony Solutions Inc.'s KonyOne platform, or Antenna Software Inc.'s Antenna Mobility Platform, or mobile consumer application platforms, including PhoneGap and Appcelerator Titanium"( Accenture, 2012). A native application offers access to a mobile handset's "sensing, capturing and storing capabilities". Such applications run like "stand-alone desktop applications", and they function "within the operating environment of the mobile phone". They can hence manoeuvre with the mobile device's features and in turn, they have the capability to offer better interpretation of information by accessing "geographic information such as the handset's GPS, compass and cell tower triangulation". Overall such applications offer higher customer engagement and customer delight ( Berg, 2011).

Developers also work on mobile web(site) which is a "collection of webpages" designed for the browsers on mobile devices. Due to the evolution of innovative webkits ("a webpage rendering engine") mobile sites become more capable and can go beyond simply serving HTML( Berg, 2011).

\section{MOBILE APPLICATIONS AND INNOVATION: TOP MOBILE APPLICATIONS FOR FUTURE}

Smartphones carry access to unique applications which focus on supporting business activities, entertainment and providing mobility and flexibility (Lee and Shim, 2006). Each smart phone has an application store where the consumers can download varied applications out of which some are free and some are paid. Innovations in mobile applications have extended the principles of social marketing as well and two such examples include 'Application Laboratory' and 'Mobile Health Monitoring'.

Application Laboratory: In Uganda, Google has joined hands with Grameen Foundation and MTN Uganda, country's leading mobile telephony provider, to launch Application Laboratory (App Labs) which provides information to the underserved of the society. App Labs provides to the citizens of Uganda applications like the Farmer's Friend which offer advice on agriculture as

Journal of Technology Management for Growing Economies, Volume 3, Number 2, October 2012
Innovations Around Mobile Applications 
Rishi, M.

well as weather, Health Tips offering advice on sexual issues and other health related problems, Clinic Finder that helps in locating clinics and Google Trader that matches agricultural products' buyers and sellers and also traders of other services( Anon, 2009).

Mobile Health Monitoring: This is a system aimed at self care and managing health on a daily basis. The technology involves a wearable device or a device that can be implanted which performs functions around a clinical issue based on embedded software's. Its functions can range from respiration sensor, temperature sensor, step counter surface ECG and a lot more. The aim of this tele-service is to facilitate communication between the patient and the health care professional (Jones et. al, 2010).

Gartner Research (2012) has identified the top consumer mobile applications for the coming years, as the following ten services:

1. Location Based Services which are context aware and include transportation systems or "city wide information systems". They also include GPS systems which are easily accessed through mobile phones because of the advancement in technology towards creating "higher resolution optical sensors", micro-satellites and radars with high resolution (Meier, 2010; Johnson, 2008). Gartner Research (2012) suggests that due to the ability of such applications, to provide context based services, these will garner a consumer base of 1.4 billion by 2014 .

2. Social Networking applications can be browser- based (Facebook) or client-based applications( Twitter) and allow( through servers), the sharing of information with users "based on user preferences and social connections"( Ryan, 2011).

3. Mobile Search empowers the consumers to perform search from their smartphones. Google, the search giant of the world, has pre-empted this demand and has created mobile search that is capable of performing search by talking to the search engine, by inputting concepts or pictures that could cue-off search results and has personalised the search to offer more relevant results .

4. Mobile Commerce is currently an extension of e-commerce but is expected to become like part of a retailer's ERP( Enterprise Resource Planning) system enabling the outlet to know the mobile "check- in" of the user

5. Mobile payment allows users to pay bills and other receipts through mobile phones, just like online payments. It offers ease and convenience and works in collaboration with the mobile carrier, banks, mobile vendors, regulators 
as well as consumers. An example to such a service is m-chek that allows people to pay mobile bills, book movie tickets, pay insurance premiums, electricity bills and recharge mobile balance by using the mobile phone (mchek, 2010).

6. Context Aware Service offer extensive user experience by offering customised content based on users' " interests, intentions, history, environment, activities, schedule, priorities, connections and preferences". Pervasive gaming is an example of this( Guo, 2012).

7. Object Recognition enables the identification of the surroundings of a user based on either the mobile handset's camera or other device senors. Google Goggles (users can take a picture from their mobile phone and use that picture as a query in the Google search) is an example of the same

8. Mobile Instant Messaging or MIM is the service that facilitates text based communication from the mobile phones. Instant messages from the mobile phone can be sent either through the browser on the mobile or the embedded IM clients on the mobile device ( The Times of India, 2006).

9. Mobile e-mail reuses already developed technologies and skills thereby making it's cost of development low. It is estimated that around 713 million users will access e-mails through mobiles by 2014

10. Mobile Video allows users to imitate their video viewing habits on webbrowsers, on mobile devices as well. This is facilitated by tie ups with Video watching platforms like YouTube.

\section{GROWING CATEGORIES OF MOBILE APPLICATIONS}

Since the growth in the usage of mobile applications, the following five categories of applications achieved highest growth rates in 2011-2012, (based on the time spent per active user)( Flurry Analytics, 2012). Elucidation of these categories gives a holistic view of the innovations, globally, in mobile applications and these categories will serve as variables for analysing the scope for Indian Mobile application Developers.

Photo \& Video: Applications in this category allow users to suitably capture and share (even edit) pictures and videos. Such applications have lead to a rapid increase in video viewing on mobile devices rather than through computer based browsers.

Music: Innovative applications in this category allow users to connect to various songs that the user might like, based on the genre of music that the user

Journal of Technology Management for Growing Economies, Volume 3, Number 2, October 2012
Innovations Around Mobile

Applications 
is listening to or the type of artist that the user listens to. Some applications also allow users to search for a particular track by simply recording a sample and allowing the application to search up the exact track from millions others.

Productivity: Applications in this category range from, ones that keep a track of the notes, photos, snapshots and voice recordings in the phone and offers them back to the user, to ones that merges smart calendaring with a To-Do-List. Users can perform translations, navigate directions, manage voicemail ,sync desktop applications with mobile and do much more with productivity applications.

Social Networking: Applications in this category offer connectivity to social media platforms like Facebook, Twitter, LinkdIn etc.

Entertainment: Mobile applications are not just centred towards business and productivity but there are several business applications that are based on fun. This category offers applications that light up the phone with LED's when it rings, drawing applications, pervasive games and other games.

\section{MOBILE APPLICATIONS AND INDIAN DEVELOPERS}

Mobile application developers in India are fast rising due to the prolific growth in this industry globally. Interestingly, in India as well as in countries like Brazil and Russia, users of mobile applications are becoming increasingly involved and consider applications an "emotionally important" part of their lives. 76\% users buy smartphones either to access Internet through the phones or to use mobile applications( Ericsson ConsumerLab Report, 2012). This is a strong indication for Indian application developers, for focusing their expertise in this industry.

The mobile application development market is expected to grow at a rate of 22.6\%, from 2011, to reach $\$ 227$ million in 2012 (Hindu Business Line, 2012) ${ }^{\mathrm{A}}$. Indian Companies that are into mobile application development, have been hiring extensively from top institutions( IIT's) from the country and young graduates are seeking a career in this nascent industry (Syan, 2012). The reasons for this accelerated growth lie in social computing, cloud computing, new methods of application development, new "software delivery models"( Biztech2, 2012), increased disposable income amongst Indians, "colossal wireless subscriber base" and growth in social networking( ResearchonIndia, 2012). Innovations in the Indian Mobile Application market range from the development of financial applications which collate information, from various credible financial portals, and bring it on a single platform for the users, to creation of applications that allow users to order eatables sitting at home. However, in India, the number of developers is not more than 1000, who are either employed with the "estimated 50 companies" or work as entrepreneurs/ freelancers (Rediff, 2009) .

Journal of Technology Management for Growing Economies, Volume 3, Number 2, October 2012 
Table 1: Categories of mobile applications : Applications by Indian Developers

\begin{tabular}{|c|c|}
\hline Category & Application \\
\hline \multirow[t]{3}{*}{ Photo \& Video } & $\begin{array}{l}\text { Special Effect ( a popular app but only for iPhone. The developers: Twist } \\
\text { Mobile, are the first Indian app company to set up shop internationally) } \\
\text { (Nair, 2012) }\end{array}$ \\
\hline & $\begin{array}{l}\text { AirGol( allows users to capture videos and share realtime. Received } \\
\text { Best Mobile App award 2012, Silicon India)(Ongraph, 2012) }\end{array}$ \\
\hline & $\begin{array}{l}\text { Drona-V-Cast ( Offers effective "video- based courses to senior } \\
\text { executives")(Lobo, 2011) }\end{array}$ \\
\hline Music & $\begin{array}{l}\text { Coke Studio (MTV's show with more than } 41 \mathrm{mn} \text { viewers on TV, } 3.4 \\
\text { mn views on YouTube, } 9.4 \text { lakh likes on Facebook) (Nandi, 2012) }\end{array}$ \\
\hline \multirow[t]{6}{*}{ Productivity } & Nightstand( No1 paid application in US's app store (Syal, 2012) \\
\hline & Wonderful Day (No.2 in the USA) (Syal, 2012) \\
\hline & $\begin{array}{l}\text { MakeMyTrip ( "amongst top } 5 \text { most downloaded travel apps in India") } \\
\text { (Hindu Business Line, 2012)B }\end{array}$ \\
\hline & $\begin{array}{l}\text { PocketSMS (Special Recgnition award at mBillionth South Asia } \\
\text { Awards 2012) (Pain, 2012) }\end{array}$ \\
\hline & $\begin{array}{l}\text { Smart Rickshaw Network (Won "m2work,"world bank sponsored" } \\
\text { award) (NDTV, 2012) }\end{array}$ \\
\hline & $\begin{array}{l}\text { Kisan Raja ( } 1^{\text {st }} \text { runners up for Samsung innovation Quotient) (Shinde, } \\
\text { 2012) }\end{array}$ \\
\hline \multirow[t]{2}{*}{$\begin{array}{l}\text { Social } \\
\text { Networking }\end{array}$} & $\begin{array}{l}\text { RockeTalk ( Car talk social community with heavy participation) } \\
\text { (Shinde, 2012) }\end{array}$ \\
\hline & $\begin{array}{l}\text { Don' the Social Mobsters' ( Social Game which is rapidly becoming } \\
\text { popular) (Law, 2012) }\end{array}$ \\
\hline \multirow[t]{5}{*}{ Entertainment } & Parking Frenzy( Topmost app. In US, UK) (Syal, 2012) \\
\hline & Super Badminton (First ever badminton app game) (Syal, 2012) \\
\hline & $\begin{array}{l}\text { Go Puzzle pro, Zulux, Dragger (Games by Twist Mobile that garnered } \\
\text { more than } 50 \text { million downloads) (Nair, 2012) }\end{array}$ \\
\hline & Birdie This ( Popular as a meditation app with Om sound) (Lobo, 2011) \\
\hline & $\begin{array}{l}\text { The Dark Man ( The game has won "24FPS } 2011 \text { MAAC International } \\
\text { Animation Award", "FICCI (BAF)-2011 Award" and "CSI (Computer } \\
\text { Society of India)-2011 Appreciation Award") (Iyer, 2012) }\end{array}$ \\
\hline
\end{tabular}

Journal of Technology Management for Growing Economies, Volume 3, Number 2, October 2012
Innovations Around Mobile Applications 
Rishi, M.

\begin{tabular}{|l|l|}
\hline & $\begin{array}{l}\text { CrickWC2011 (“Cricket Feed Aggrigator app, which was No3 on Apple } \\
\text { store during World Cup) (Shrivastava, 2011) }\end{array}$ \\
\hline & $\begin{array}{l}\text { Hit21 Deluxe ( Game won "Nokia calling all innovators" Award 2011) } \\
\text { (The Economic Times, 2011) }\end{array}$ \\
\hline
\end{tabular}

Table 1 showcases some of the top applications (across categories) that have Indian origin and have made a mark amongst global as well as national users. It is evident from the data presented in Table 1 that remarkable applications by Indian developers are rather limited, in some of the most popular categories. Though some Indian Application development companies have been bringing out applications around utility/ productivity and entertainment/fun, yet the scope for creative exploration in the application development market, is huge for India. Developers in our country have to work on innovative applications that can become an integral part of the consumers' work life, social life and emotional well-being ( Shinde, 2012).

\section{SCOPE FOR INDIAN MOBILE APPLICATION DEVELOPERS: MANAGERIAL IMPLICATIONS}

The application development industry has great potential for the Indian developers since technologies have evolved and creating an application that can touch the lives of millions of millions of global users, is no more restricted to the industry giants. Indian application developers can leverage the trends of existing consumer excitement and involvement with mobile applications and the following observations can assist the growth of the Indian counterpart of the Application Software Development Industry.

- Working on "Cloud-enabled" mobile applications; the developers can create highly user-centric applications. For the same, Indian developers need to focus on accessing "elastic resources for software testing" (Tejaswni, 2012) to ensure that the developed applications offer high customer delight.

- It is critical for Indian developers to create applications with global acceptability potential because it is believed that if mobile application developers triple the number of users, by making apps with a global appeal, their revenues too increase phenomenally (Google Developers, 2012). Indian mobile application developers must evaluate the degree of Internationalisation v/s localisation( in terms of custom features or when text does not get rendered correctly, during translation) required for developing a successful application. However to achieve so, the 
applications have to be launched in multiple languages. Some popular applications today, are available in more than 40 languages and Indian developers must progress towards adapting the same trend.

- Indian Mobile application developers need to " transparently synchronize data with backend systems"( Accenture, 2012). They must, while application development, take into consideration that the developed innovation has least security threats and can offer users an experience even when they are offline.

- The entrepreneurs in this industry can look at beginning their development centres in Tier II and Tier III cities. These cities and smaller towns have a cost advantage of about 30- 40\% (Nair, 2012), as compared to the metro cities.

- Indian mobile application developers must focus on developing apps. that are India- centric, based on Indian religious, mythological, cultural, historical and psychographic dimensions. Currently very few applications are available on similar lines and a huge untapped market potential lies in this area. Indian applications targeted especially at the rural areas, with assistance to farmers, or applications that could communicate with rural women as well as children in their own language, would prove to be a coveted innovation.

- Indian Developers must create applications, keeping in mind the price sensitivity of the consumers (Rediff, 2009). For cost advantages, besides choosing location prudently, application developers can convince the application stores( like Apple's ; RIM's and Android) about offering an excellent customer experience. Application stores usually host $30 \%$ cost of development in that situation (Rediff, 2009).

- Just signing a deal with the app store ( for Apple App Store it is a membership for iOS Development Program; while Nokia Ovi Store and Android allow developers to upload freely (Krishnaswami,2012)) is insufficient. Developers need to ensure that their apps feature in the 'Latest' section or an equivalent section for each app store and simultaneously applications must be promoted on popular social networking platforms as well. Indian developers need to ensure that their apps. are tagged under appropriate keywords and are beta tested, to ensure targeted marketing of the application.

\section{Conclusion}

Mobile application market is based on the amalgamation of technology with
Innovations Around Mobile

Applications 
Rishi, M.

basic( as well as advanced) needs of the consumers, pertaining to business, fun, entertainment and productivity. Consumers today expect that information should be available to be them, within fraction of seconds, on, not just desktops but on their mobile phones, which stay with them all the time. Also it is forecasted that mobile (smartphone market) will be bigger than Internet by the year 2015 (Morgan Stanley, 2010). In the light of this scenario, it is evident that mobile applications' market has great potential for the future. However the survival of mobile applications would primarily depend on the user experience that the application creates, the pricing and affordability of the applications as well as the way they connect with the overall width of application Ecosystem (Morgan Stanley, 2010). Today, mobile applications aim at offering higher user interface by being accessible easily, by processing faster and offering shortcuts that are available directly on the phone screen. Applications are also designed in a way that they do not interfere with other functions being performed on the mobile device, while running simultaneously.

This research has explored varied innovations around mobile applications (Indian and International) and it is recommended that mobile applications' development companies must focus on the up- gradation of technology in a way that aspects like longer battery life, compatibility with the present operating systems and better user interface/ experience, are clearly taken care of. Mobile applications also have a dreary cloud of security issues engulfing them. These security threats come from multiple reasons which are:

- Large information pool which is shared and accessed by users (facilitated by improving technologies, storage capabilities of mobile devices and their enhanced interface)

- Enhanced technologies like GPS which can locate a "terminal's position" accurately.

- Mobile phones and devices today can be connected with each- other, with information clouds and if left on the "Always-On" mode, they could not just update applications and technologies real-time but can also raise security issues(Edwards, 2002) revolving around privacy, virus downloads, information's sharing violation etc.

Considering this background, it is recommended that, to ensure higher security of the device and its user, the information or applications accessed and shared should not rely upon the network for its proper functioning because, as cited by Talukder and Yavagal( 2005), a user can easily change from one device to the other or one network to the other. Finally, since the mobile application market is gaining customer trust, all over the world, it makes brilliant marketing sense 
for mobile applications' developers to create applications aimed at specific target groups. This can be done by including special features, specific user interface and ease of access (in terms of paid/ non-paid). Eventually the final aim has to be the achievement of customer delight through technology supported marketing innovations.

\section{REFERENCES}

Accenture (2012), 'Mobile Application Development: Challenges and Best Practises', Accenture, USA.

Anonomous (2009) Mobile phones empower Uganda, Appropriate Technology, 36: 4, pp. 36.

Berg, R( 2011), 'Industry Innovations: A mobile application interview with Bob Evans', The Journal of Insurance Operations, March 2011.

Berger, A. A. ( 2012), 'Media Analysis Techniques'( $4^{\text {th }}$ Ed.), Sage Publication, USA, pp. 135

Biztech2 ( 2012), 'India App development market to reach \$227 mn in 2012', Online. Biztech2. com. Available at http://biztech2.in.com/news/applications/india-app-development-mktto-reach-\$227-mn-in-2012/142002/0. Cited on 27-8-12.

Bloch, J. ( 2006), How to design a good API and why it matters, Key note in Conference on Object Oriented Programming Systems Languages and Applications, NewYork.

Cnet Reviews (2020). Best Smartphones. Accessed on $15^{\text {th }}$ September 2010. Available at http:// reviews.cnet.com/best-smartphones/.

ComScore, 2010 (Online), “ The State of the Global Internet - with a Focus on Asia”. Webnair accessed on Wednesday, $2^{\text {nd }}$ July 2010 at 10:00 am. Report available at http://www. comscore.com/Press_Events/Press_Releases/2008/06/Top_Asia-Pacific_Search_Engines.

Daily Nation (2012), 'Privacy and security in the era of mobile applications and multiple stores'. Online. Accessed from http://www.nation.co.ke/Tech/Privacy+and+security+in+the+era+ of+mobile+apps/-/1017288/1487706/-/y3kd0c/-/index.html. Cited on 27-8-12 .

ECMA International(2002), Near Field Communication. Accessed on 14 ${ }^{\text {th }}$ September 2010. Available at http://www.ecma-international.org/activities/Communications/2002tg19-010. pdf

Edwards, N. H. ( 2002), Priorities for future research in privacy and security for mobile applications( Internet). PAMPAS project funded by EU's Fifth Framework Programme. Cited on $7^{\text {th }}$ Oct 2010. Available at http://www.pampas.eu.org/Position_Papers/BTexact. pdf

Ericsson ConsumerLab Report (2012), 'Emerging App Culture', pp. 3-4

Euzenat, Jerome; Pierson Jerome and Ramparany Fano( 2008), Dynamic context management for pervasive applications, The Knowledge Engineering Review, 23:1, pp. 21-49.

Flurry Analytics( 2011), 'Mobile App Growth Led by Video Sharing: YouTube in the Crosshairs?'. Online. Accessed on http://blog.flurry.com/bid/84831/Mobile-App-GrowthLed-by-Video-Sharing-YouTube-in-the-Crosshairs. Cited on 26/8/12.

Gartner Research (2012), 'Mobile Insight: Ten Consumer Mobile Applications to Watch in 2012', Online. Accessed from http://www.gartner.com/it/page.jsp?id=1544815. Cited on 27-8-12.

Google developers (2012), 'Google I/O 2012 - Developing for a Global Audience: Tools for Localization and Internationalization'. Online Video. Accessed on $5^{\text {th }}$ Sept. 2012. Available at http://www.youtube.com/watch?v=xSGA19rG_D8.

Guo, B., Fujimura R., Zhang, D. and Imai, M. (2012), 'Design- in-play: Improving the
Innovations

Around Mobile

Applications 

dx.doi.org/10.1007/s11042-010-0711-z.

Gupta, M. P., Sahu, G. P. and Gauri, S. (2005), Assessing Impact of mobile communications on organisations: A Flexibility Analysis, Global Journal of Flexible Systems Management, 6:3/4, pp. 11

Gyorbiro, N., Fabian, A. and Homanyi, G. ( 2008), An activity recognistion system for mobile phones, Springer Science+Business Media, Published Online, November 2008. http:// dx.doi.org/10.1007/s11036-008-0112-Y.

Hindu BusinessLine(2012)A, 'Indian app software market will cross \$227 m this year: Gartner'. Online. Accessed from http://www.thehindubusinessline.com/industry-and-economy/infotech/article3817096.ece. Cited on 29-8-12.

Hindu BusinessLine(2012) ${ }^{\mathrm{B}}$, 'Makemytrip launches comprehensive mobile suite', Accessed from http://www.thehindubusinessline.com/industry-and-economy/marketing/article3627559. ece. Cited on 30-8-12 .

Indian Readership Survey Q4(2011), Online. Accessed from http://www.bestmediainfo. com/2012/03/irs-q4-2011-top-10-english-dailies/. Cited on 26 $6^{\text {th }}$ Aug 2012.

Iyer, KSS (2012), '7Seas launches teh Dark man for Android Devices'. Online. Accessed from http://gadgets.ndtv.com/apps/news/7seas-launches-the-dark-man-for-android-devices-256153. Cited on 31-8-12.

Johnson, S. P. (2008), Google earth, Microsoft Virtual Earth and Yahoo Maps dictate global mapping models, The Business Review Cambridge, 11:1.

Jones, V., Gay, V. and Leijdekkers, P. (2010), Body Sensor networks for Mobile Health Monitoring: Experience in Europe and Australia, Accepted for: The Fourth International Conference on Digital Society, ICDS 2010, February 10-16, 2010 - St. Maarten, Netherlands Antilles, CPS 2010. http://dx.doi.org/10.1109/ICDS.2010.41.

Kenney, B. (2007) Apple's iPhone: Technology Product of the Year (online) Accessed on $23^{\text {rd }}$ September, 2010. available at http://www.industryweek.com/articles/apples_iphone_ technology_product_of_the_year_15288.aspx.

Krazit, T. and Shankland, S. ( 2009), Google launches Real Time Search, Cnet News (Online). $7^{\text {th }}$ December 2009. Accessed on $12^{\text {th }}$ September 2010. Available at http://news.cnet.com/830130684_3-10410599-265.html.

Krishnaswami, N( 2012), 'App Stores: What Indian developers need to know'. Online. Accessed fromhttp://articles.timesofindia.indiatimes.com/2012-03-06/computing/31126609_1_appstores-google-s-android-market-app-developer/2 Cited on 31-8-12.

Law, A. ( 2012), 'Developing India's App Market'. Hindu Business Line. Online. Available at http://www.thehindubusinessline.com/features/eworld/article3266515.ece. Cited on 5th Sep 2012.

Lee, C. and Shim, J. (2006), An empirical research on user satisfaction with mobile business applications use and hedonism, JITTA : Journal of Information Technology Theory and Application, 8:3, pp. 57.

Lobo, A. ( 2011), 'The Great Indian Mobile App', Accessed from http://articles.economictimes. indiatimes.com/2011-08-19/news/29905434_1_mobile-apps-app-store-informate-mobileintelligence. Cited on 31-8-12.

Maamar, Z. ( 2006), A Mobile Application based on Software Agents and mobile web services, Business Process Management Journal, 12:3, pp. 311. http://dx.doi. org/10.1108/14637150610667980.

MChek( 2010). Accessed on $14^{\text {th }}$ September 2010. Available at http://main.mchek.com/.

Journal of Technology Management for Growing Economies, Volume 3, Number 2, October 2012 
McLean, P. ( 2009), Canalys: iPhone outsold all windows mobile phones in Q2 2009, AppleInsider( online). Accessed on $12^{\text {th }}$ September 2009. Available at http://www. appleinsider.com/articles/09/08/21/canalys_iphone_outsold_all_windows_mobile_ phones_in_q2_2009.html.

Meier, R. ( 2010), On Event Based Middleware for Location Aware Mobile Applications, IEEE Transactions on Software Engineering, 36;3. http://dx.doi.org/10.1109/TSE.2009.90.

Miettinen, A.P., and Nurminen, J.K. (2010) Energy efficiency of mobile clients in cloud computing. Online accessed on September 18, 2010. Available from www.usenix.org/ event/hotcloud10/tech/slides/miettinen.pdf

Miller, M, ( 2010), Top 10 SmartPhones of 2010...for now. ZNet( Online).21 ${ }^{\text {st }}$ May 2010., Accessed on $15^{\text {th }}$ September 2010. Available at http://www.zdnet.com/blog/cell-phones/ top-10-smartphones-of-2010-for-now/3854.

Morgan Stanley( 2010), Internet Trends report, April 12, 2010, pp. 13.

MSN Gadgets( 2010), Sub Rs 6000 Smartphones: Nokia takes on local Indian rivals. Online. msn.com. Accessed on $6^{\text {th }}$ Oct 2010. Available at http://computing.in.msn.com/gadgets/ news/article. .aspx ?cp-documentid $=3863835$.

Nandi, S. ( 2012), 'Youth channels crack teh digital code'. Online, Accessed from http://www. exchange4media.com/47639_youth-channels-crack-the-digital-code.html. Cited on 31-812.

NDTV (2012), 'Indian's “Smart Rickshaw Mobile app wins innovative prize'. Online. Accessed from http://gadgets.ndtv.com/apps/news/indians-smart-rickshaw-mobile-app-wins-innovation-prize-223314. Cited on 31-8-12.

Neuendorf, KA ( 2002), 'The Content Analysis Guidebook', Sage Publication, UK, pp 49- 50

Ongraph (2012), 'On Graph Technologies'. Online. Available at http://www.ongraph.com/. Cited on $5^{\text {th }}$ Sep. 2012.

Pain, P. (2012), 'Now the Blind and Deaf can read and send SMS', Online. The Hindu. Accessed from http://www.thehindu.com/sci-tech/technology/article3318264.ece. Cited on 30-8012.

Palmer, J. (2009) Second Google Phone is Unveiled. BBC News. Posted on 17 $7^{\text {th }}$ Feb 2009. Online accessed on $30^{\text {th }}$ September, 2010. Available at http://news.bbc.co.uk/2/hi/7894516. stm.

PC World( 2012), 'The 101 best mobile applications'. Accessed on http://www.pcworld.com/ article/203633/the_101_best_mobile_apps.html. cited on 26/8/12.

Poitou, Jean-Laurent, (August 2011), Emerging markets fuel demands for smartphones,

Rasheed, H( 2012), 'Innovation Strategy', iUniverse Publishing, NY, pp. 188.

Rediff (2009), 'Mobile apps prove a boon for Indian developers'. Online. Accessed from http://business.rediff.com/report/2009/nov/19/tech-mobile-apps-prove-a-boon-for-indiandevelopers.htm. Cited on 31-8-12.

ResearchonIndia (2012), ' Mobile Application Market in India'. Online Video. Accessed from http://www.youtube.com/watch?v=-cGTdPqk7cw. Cited on $5^{\text {th }}$ Sep, 2012.

Ryan, PK( 2011), 'Digital and Information Literacy: Social Networking', The Rosen Publishing Group, NY, pp. 7-8.

Sapolsky, BS; Molitor F and Luque S( 2003), 'Sex and violence in Slasher Films: Re-Examining the assumptions', 'Journalism and Mass Communication Quarterly', 80:1, pp. 28- 38. http://dx.doi.org/10.1177/107769900308000103.

Satyanarayanan, M and Narayanan, Dushyanth (2001), Multi Fidelity Algorithms for Interactive Mobile Applications, Wireless Networks, 7: 6, pp. 601. http://dx.doi. org/10.1023/A:1012315301312.

Journal of Technology Management for Growing Economies, Volume 3, Number 2, October 2012 
Rishi, M.
Scmitt, J., Hollick, M., Roos, C. and Steinmetz, R. (2008), Adapting the user context in realtime: Tailoring online machine learning algorithms to ambient computing, Springer Science+Business Media (Published Online), October 2008. http://dx.doi.org/10.1007/ s11036-008-0095-8.

Shinde, S. ( 2012), 'Think innovation: Mobile apps ride on rural India'. Online. Accessed from http://www.business-standard.com/india/news/think-innovation-mobile-apps-rideruralindia-/449592/. Cited on 31-8-12.

Shrivastava I (2011), ' Cricket apps ride WorldCup wave'. Time of India Online.. Available at http://timesofindia.indiatimes.com/business/india-business/Cricket-apps-ride-World-Cupwave/articleshow/7566288.cms. Cited on 5th Sep 2012.

Syal, S. ( 2012), 'Mobile apps developed by Indian ventures notching up millions of downloads on global stores'. Online. Economic Times. Cited from http://articles.economictimes. indiatimes.com/2012-07-27/news/32889364_1_mobile-application-mobile-devicesmobile-game. Cited on 29th Aug 2012.

Tarnacha, A. and Maitland, C. (2008), Structural Effects of Platform Certification on a Complementary Product Market: The case of Mobile Applications, Journal of IT Standards and Standardisation Research, 6:2, pp. 48- 65. http://dx.doi.org/10.4018/978-1-60566946-5.ch015.

Tejaswni, M. J. (2012), 'Cloud is changing the way applications are designed, tested and deployed'. Online. Times Of India. Available at http://articles.timesofindia.indiatimes. com/2012-08-24/bangalore/33365906_1_open-source-software-asheesh-raina-gartner. Cited on 26-8-12.

The Economic Times (2011), 'The Great Indian Mobile App'. Online. Available at nextwavemultimedia.com/blog/wp-content/uploads/2011/01/et-19jan113.jpg. Cited on $5^{\text {th }}$ Sep 2012.

The Times of India ( 2006). Mobile IM, The SMS alternative?( Online). Accessed on $20^{\text {th }}$ September 2010. Available at http://timesofindia.indiatimes.com/business/india-business/ Mobile-IM-The-SMS-alternative-/articleshow/291568.cms.

Wimmer, RD and Dominick, JR( 2011), 'Mass Media Research: An Introduction', Cengage learning, USA, pp. 157-158.

Meghna Rishi, is Assistant Professor, Lal Bahadur Shastri Institute of Management, New Delhi, India. Email: meghna.14@gmail.com.

Journal of Technology Management for Growing Economies, Volume 3, Number 2, October 2012 